\title{
Reactive Oxygen Species Mediates Lysophosphatidic Acid-induced Migration of SKOV-3 Ovarian Cancer Cells
}

\author{
Eun Kyoung Kim', Hye Sun Lee', Hong Koo Ha², Sung Ji Yun', Jung Min Ha', Young Whan Kim', \\ In Hye Jin', Hwa Kyoung Shin ${ }^{1}$ and Sun Sik Bae* \\ ${ }^{1}$ MRC for Ischemic Tissue Regeneration, Medical Research Institute, Department of Pharmacology, Pusan National University School at \\ Medicine, Yangsan 626-870, Korea \\ ${ }^{2}$ Department of Urology, Pusan National University Hospital, Busan 602-739, Korea \\ ${ }^{3}$ Department of Anatomy, Pusan National University School of Korean Medicine, Yangsan 626-870, Korea
}

Received November 13, 2012 /Revised November 27, 2012 /Accepted December 4, 2012

\begin{abstract}
Cell motility plays an essential role in many physiological responses, such as development, immune reaction, and angiogenesis. In the present study, we showed that lysophosphatidic acid (LPA) modulates cancer cell migration by regulation of generation of reactive oxygen species (ROS). Stimulation of SKOV-3 ovarian cancer cells with LPA strongly promoted migration. but this migration was completely blocked by pharmacological inhibition of phosphatidylinositol 3-kinase (PI3K)/Akt signaling pathway. Inhibition of the ERK pathway had no effect on migration. Stimulation of SKOV-3 ovarian cancer cells with LPA significantly induced the generation of ROS in a time-dependent manner. LPA-induced generation of ROS was significantly blocked by pharmacological inhibition of PI3K or Akt, but inhibition of the ERK signaling pathway had little effect. LPA-induced generation of ROS was blocked by pretreatment of SKOV-3 ovarian cancer cells with an NADPH oxidase inhibitor, whereas inhibition of xanthine oxidase, cyclooxygenase, or mitochondrial respiratory chain complex I had no effect. Scavenging of ROS by N-acetylcysteine completely blocked LPA-induced migration of SKOV-3 ovarian cancer cells. Inhibition of NADPH oxidase blocked LPA-induced migration whereas inhibition of xanthine oxidase, cyclooxygenase, or mitochondrial respiratory chain complex I did not affect LPA-induced migration of SKOV-3 ovarian cancer cells. Given these results, we suggest that LPA induces ROS generation through the PI3K/Akt/NADPH oxidase signaling axis, thereby regulating cancer cell migration.
\end{abstract}

Key words : Lysophosphatidic acid (LPA), reactive oxygen species (ROS), migration, NADPH oxidase, phosphatidylinositol 3-kinase (PI3K)

\section{Introduction}

Cell migration plays crucial roles in both physiology and pathophysiology such as embryonic development, immune system activation, angiognenesis, inflammation, wound healing, and cancer cell metastasis $[18,26,28]$. The speed and direction of cell migration are controlled by complex mechanisms involving morphological changes. For example, membrane rufflings such as laemellipodia and filopodia are formed by dynamic coordination of cytoskeletal rearrangement $[18,28]$. Major responsible factors for morphological

\footnotetext{
*Corresponding author

Tel : +82-51-510-8065, Fax : +82-51-510-8068

E-mail : sunsik@pusan.ac.kr

This is an Open-Access article distributed under the terms of the Creative Commons Attribution Non-Commercial License (http://creativecommons.org/licenses/by-nc/3.0) which permits unrestricted non-commercial use, distribution, and reproduction in any medium, provided the original work is properly cited
}

change and directional migration are known to be microtubules, integrins, and small $G$ proteins such as Rac and CDC42 $[6,7,35]$. Directionality of cell migration is acquired by local activation of Rac or Ras where its local activation of phosphatidylinositol 3-kinase (PI3K) renders establishment of phosphoinositide gradient at the plasma membrane [30,33]. Basically, PI3K catalyzes phosphatidylinositol 4,5-bis phosphate $\left(\mathrm{PIP}_{2}\right)$ to generate more acidic phospholipid, phosphatidylinositol 3,4,5-trisphosphate ( $\left.\mathrm{PIP}_{3}\right)$. Accumulation of $\mathrm{PIP}_{3}$ at membrane ruffling region enables cells to recruit a number of signaling molecules including Rac guanine nucleotide exchange factors (GEFs) and downstream effector molecules such as Wiskott-Aldrich syndrome protein (WASP) and WASP-family verprolin homologous protein (WAVE) $[9,23,29]$.

In normal serum or body fluids, a lipid ligand, lysophosphatidic acid (LPA, 1- or 2-acyl-sn-glycero-3-phosphate) normally exists. High level of LPA is detected not only in ascitic 
fluids but also in the plasma of ovarian cancer patients thereby regarded as a biomarker for ovarian cancer [37]. LPA modulates many cellular physiologies. In particular, it has been reported that LPA stimulates migration in various cell types including endothelial cells and fibroblasts [24,25]. In addition, LPA modulates migration of cancer cells such as ovarian cancer cells and rat hepatoma cells [8,14]. Recently, it also has been reported that LPA synergistically induces cancer cell migration in the presence of growth factors [15].

The mechanism by which LPA regulates cancer cell migration is still unclear. It has been reported that LPA activates $G$ protein-coupled receptors (GPCRs) such as $\mathrm{LPA}_{1} /$ Edg-2, LPA 2 /Edg-4, and LPA 3 /Edg-7LPA thereby exerts its biological function [5]. Occupation of LPA receptors by LPA triggers signaling activation to induce migration in a variety of cells. For example, LPA activates the Ras/ $\mathrm{MEKK} /$ mitogen activated protein kinase (MAPK) pathway, p38 mitogen-activated protein kinase (p38 MAPK), and c-Jun N-terminal kinase (JNK) [2,21]. In addition, PI3K is also activated by LPA stimulation. It has been reported that PI3K is activated by two different mechanisms. For example, LPA activates class I PI3K through transactivation of epidermal growth factor (EGF) receptor or directly activates class II PI3K [20,32]. Although the involvement of PI3K in LPA-induced cancer cell migration in evident, the mechanism by which $\mathrm{PIP}_{3}$ regulates migration of cancer cell is still ambiguous. Recent evidence has supported that $\mathrm{PIP}_{3}$ can directly activate Rac small $G$ protein to induced the formation of membrane ruffling. However, further downstream of $\mathrm{PIP}_{3} / \mathrm{Rac}$ signaling pathway is still unclear.

Reactive oxygen species (ROS) are generated by many different type extracellular stimuli [19]. Particularly, LPA significantly generates ROS in both macrophages and ovarian cancer cells thereby regulate mitogen-activated protein kinase (MAPK) signaling and proliferation [3,31]. However, the involvement of ROS in LPA-induced cancer cell migration is still unclear. In this study, we suggest that LPA induces cancer cell migration through PI3K/NADPH oxidase pathways.

\section{Materials and Methods}

\section{Materials}

All culture media were purchased from Hyclone Laboratories Inc. (Logan, UT, USA). ChemoTx membrane $(8$ $\mu \mathrm{m}$ pore size) was obtained from Neuro Probe Inc.
Lysophosphatidic acid (LPA, 1- or 2-acyl-sn-glycero-3phosphate) and all other high quality reagents were purchased from Sigma-Aldrich unless otherwise indicated.

\section{Cell culture}

SKOV-3 ovarian cancer cells were maintained in Roswell Park Memorial Institute (RPMI) medium containing 10\% fetal bovine serum (FBS) and $1 \%$ penicillin/streptomycin at $37^{\circ} \mathrm{C}$ in a humidified $5 \% \mathrm{CO}_{2}$ incubator.

\section{Migration assay}

SKOV-3 ovarian cancer cells were grown and serum-starved for $6 \mathrm{hrs}$ before plating on a ChemoTx chamber. Cells were detached with trypsin-EDTA and washed with serum-free RPMI. For the migration assay, the bottom side of the ChemoTx membrane was coated with type I collagen for $30 \mathrm{~min}$ and a total of $2 \times 10^{4}$ serum-starved cells in a 50 $\mu \mathrm{l}$ volume were placed on the top side of ChemoTx membrane. Migration was induced by placing the cells on an overlaid ChemoTx membrane on top of serum-free medium either in the absence or presence of chemotactic factors such as LPA $(10 \mu \mathrm{M})$ for $3 \mathrm{hrs}$. The ChemoTx membrane was fixed with $4 \%$ paraformaldehyde, and non-migrated cells on the top side of membrane were removed by wiping with a cotton swab. The membrane was stained with DAPI, and migrated cells were counted with the fluorescence microscope at 10× magnification (Axiovert 200, Germany).

\section{ROS production assay}

To measure ROS generation, SKOV-3 ovarian cancer cells were grown in 6-well plates. After being serum starved for $12 \mathrm{~h}$, SKOV-3 cells were incubated with $20 \mu \mathrm{M}$ of $2^{\prime}, 7^{\prime}$-dichlorofluorescein diacetate (DCF-DA, Sigma-Aldrich, St Louis, MO, USA) for $30 \mathrm{~min}$ at $37^{\circ} \mathrm{C}$, and then stimulated with LPA $(10 \mu \mathrm{M})$ for $5 \mathrm{~min}$ under the indicated conditions. Cells were washed three times with chilled PBS to eliminate any interference from contaminants. Fluorescence was detected using a fluorescence microscope at $10 \times$ magnification (Axiovert200, Carl Zeiss, Jena, Germany) and quantified by MetaMorph software (Molecular Devices, Sunnyvale, CA).

\section{Statistical analysis}

Results are expressed as the mean \pm S.D. of three independent experiments ( $n=3$ for each experiment). When comparing two groups, an unpaired Student's $t$-test was used to assess differences. $P$-values less than 0.05 were con- 
sidered significant.

\section{Results}

LPA induces migration of SKOV-3 ovarian cancer cells

To ascertain capability of LPA in the induction of migration, we have examined chemotactic migration of SKOV-3 ovarian cancer cells by LPA. As shown in Fig. 1A, LPA significantly induced migration of SKOV-3 ovarian cancer cells. Since LPA activates variety of signaling molecules, we examined which one is important for the LPA-induced migration of SKOV-3 ovarian cancer cells. As shown in Fig. 1B, pharmacological inhibition of PI3K using LY294002 $(10 \mu \mathrm{M})$ significantly blocked LPA-induced migration of SKOV-3 ovarian cancer cells. In addition, inhibition of Akt by SH-5 (10 $\mu \mathrm{M})$ completely abrogated LPA-induced migration of SKOV-3 ovarian cancer cells. However, inhibition of ERK by PD98059 $(10 \mu \mathrm{M})$ did not affect LPA-induced migration of SKOV-3 ovarian cancer cells. These results suggest that PI3K/Akt signaling pathway is important for LPA-induced migration of SKOV-3 ovarian cancer cells.

LPA induces ROS generation through the activation of PI3K signaling pathway

Since ROS is generated by various extracellular stimuli
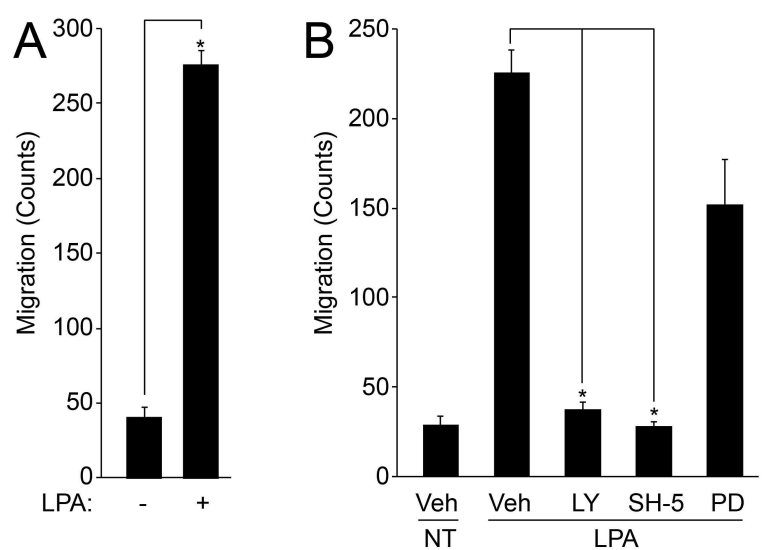

Fig. 1. LPA-induced migration of SKOV-3 ovarian cancer cells. (A) Chemotactic migration of SKOV-3 ovarian cancer cells was measured after stimulation with LPA $(10 \mu \mathrm{M})$. (B) Cells were pretreated with each pharmacological inhibitor (LY, LY294002, PI3K inhibitor, $10 \mu \mathrm{M}$; SH-5, Akt inhibitor, $10 \mu \mathrm{M}$; PD, PD98059, MEK inhibitor, $10 \mu \mathrm{M}$ ) for $20 \mathrm{~min}$ and LPA-induced migration was measured. Data are the means \pm S.D. of three independent experiments ( $n=3$ for each experiment). *Significantly different from controls $(p<0.05)$.
[19], we examined production of ROS after stimulation of SKOV-3 ovarian cancer cells with LPA. As shown in Figs. $2 \mathrm{~A}$ and $2 \mathrm{~B}$, LPA significantly induced the generation of ROS as judged by fluorescence assay. Since PI3K/Akt signaling pathway mediates LPA-induced migration of SKOV-3 ovarian cancer cells, we examined activation of Akt. As shown in Fig. 2C, LPA rapidly induced the activation of Akt within 1 min. Next, we examined the effect of PI3K or Akt inhibition on the generation of ROS. As shown in Figs. 2D and $2 \mathrm{E}$, inhibition of PI3K or Akt significantly reduced LPA-induced generation of ROS whereas inhibition of ERK signaling pathway did not affect. These results suggest that LPA evoke production of ROS through the activation of PI3K/Akt signaling pathway.

LPA induces ROS generation through NADPH oxidase system

It has been reported that xanthine oxidase, eicosanoids,
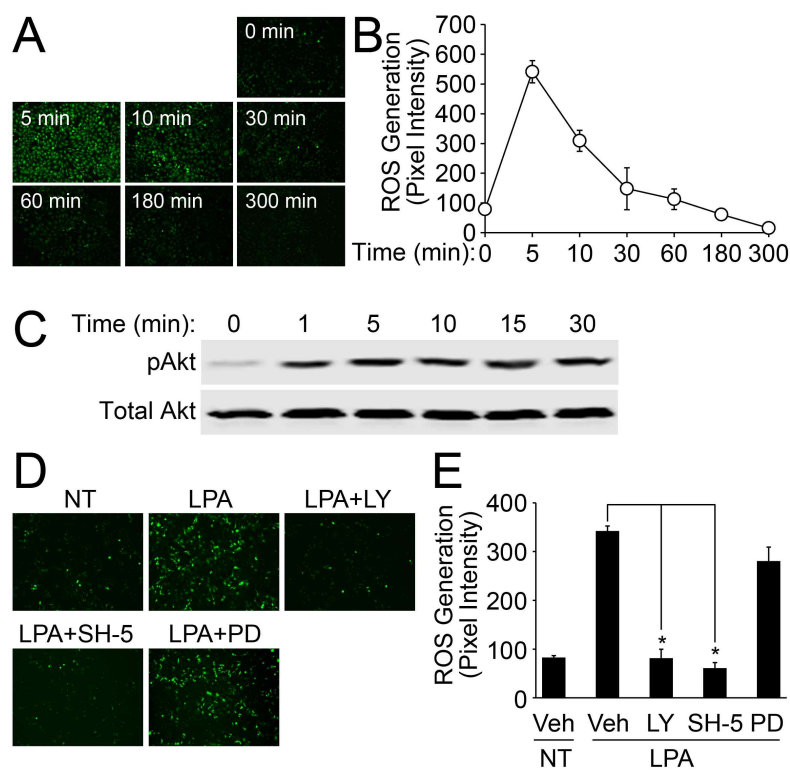

Fig. 2. Generation of ROS by LPA. (A) SKOV-3 ovarian cancer cells were stimulated with LPA $(10 \mu \mathrm{M})$ for the indicated times and generation of ROS was measured in the presence of DCF-DA $(20 \mu \mathrm{M})$. (B) Pixel intensity of images by quantified by MetaMorph software. (C) Cells were stimulated with LPA $(10 \mu \mathrm{M})$ for the indicated times and activation of Akt was verified by western blotting. (D) Cells were pretreated with PI3K inhibitor (LY, LY294002, $10 \mu \mathrm{M})$, Akt inhibitor $(\mathrm{SH}-5,10 \mu \mathrm{M})$, or ERK inhibitor (PD, PD98059, $10 \mu \mathrm{M}$ ) for $20 \mathrm{~min}$ and generation of ROS was measured in the presence of DCF-DA $(20 \mu \mathrm{M})$. (E) Pixel intensity of images by quantified by MetaMorph software. Data are the means \pm S.D. of three independent experiments ( $n=3$ for each experiment). *Significantly different from controls $(p<0.05)$. 
NADPH oxidase, mitochondrial respiratory chain belong to principal sources of ROS in cells. To delineate major source of LPA-induced ROS generation, we pharmacologically inhibited each source of ROS. As shown in Fig. 3, inhibition of NADPH oxidase system by apocyanin (Apo, $10 \mu \mathrm{M}$ ) or diphenylene iodonium (DPI, $10 \mu \mathrm{M}$ ) significantly blocked LPA-induced ROS generation whereas inhibition of xanthine oxidase, cyclooxygenase, or mitochondrial respiratory chain did not affect. These results suggest that NADPH oxidase system plays pivotal role in LPA-induced generation of ROS.

Generation of ROS is important for LPA-induced cancer cell migration

Since our results showed that LPA produces ROS through NADPH oxidase system, we examined the effect of ROS generation on the LPA-induced migration of cancer cells. As shown in Fig. 4A, scavenging ROS by $\mathrm{N}$-acetylcysteine (NAC, $10 \mu \mathrm{M}$ ) completely blocked LPA-induced migration of cancer cells. As shown in Fig. 4B, pharmacological inhibition of NADPH oxidase by either diphenylene iodonium (DPI, $10 \mu \mathrm{M}$ ) or apocyanin (Apo, $10 \mu \mathrm{M}$ ) blocked LPA-induced cancer cell migration. However, inhibition of xanthine oxidase (Allo, allopurinol, $10 \mu \mathrm{M}$ ), cyclooxygenase (Indo, in-
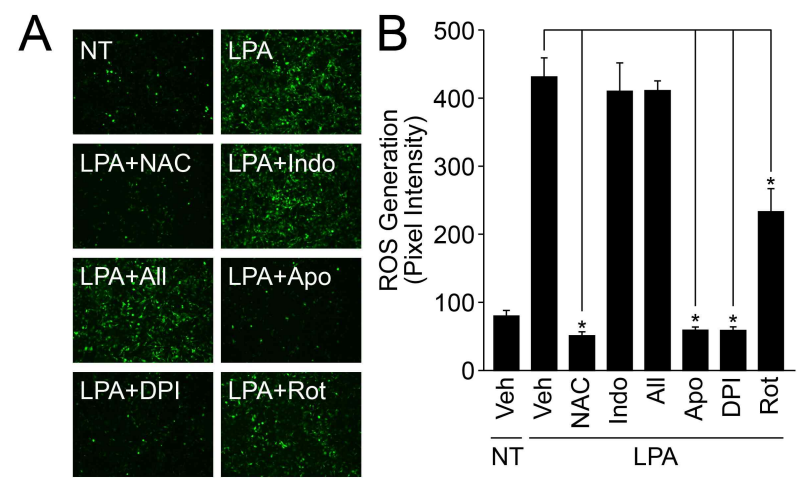

Fig. 3. Generation of ROS by NADPH oxidase. (A) SKOV-3 ovarian cancer cells were pretreated with ROS scavenger (NAC, N-acetylcysteine, $10 \mu \mathrm{M}$ ), COX inhibitor (Indo, indomethacin, $10 \mu \mathrm{M}$ ), xanthine oxidase inhibitor (All, allopurinol, $10 \mu \mathrm{M}$ ), NADPH oxidase inhibitors (Apo, apocyanin, $10 \mu \mathrm{M}$; DPI, diphenylene iodonium, $10 \mu \mathrm{M})$, or mitochondrial respiratory chain complex inhibitor (Rot, rotenone, $10 \mu \mathrm{M}$ ) for $20 \mathrm{~min}$ and stimulated with LPA $(10 \mu \mathrm{M})$ for $5 \mathrm{~min}$. Generation of ROS was measured in the presence of DCF-DA $(20 \mu \mathrm{M})$. (B) Pixel intensity of images by quantified by MetaMorph software. Data are the means $\pm S$.D. of three independent experiments ( $n=3$ for each experiment). *Significantly different from controls $(p<0.05)$. domethacin, $10 \mu \mathrm{M}$ ), or mitochondrial respiratory chain (Rot, rotenone, $10 \mu \mathrm{M}$ ) did not affect LPA-induced migration of SKOV-3 ovarian cancer cells. These results suggest that production of ROS by NADPH oxidase system plays crucial role in LPA-induced migration of SKOV-3 ovarian cancer cells.

\section{Discussion}

Plethora of reports suggests that LPA mainly activates three MAPK signaling pathways including the Ras/MEKK/ MAPK, p38 MAPK, and JNK pathways [2,21]. In addition to these MAPK signaling pathways, it also has been reported that LPA stimulates PI3K signaling pathways and regulates variety of physiological responses such as DNA synthesis and cell motility $[15,17]$. Although the mechanism underlying activation of PI3K is still unclear, inhibition of PI3K blocks almost all the LPA-induced physiological responses. Likewise, our results showed that inhibition of PI3K blocked LPA-induced migration as well as ROS generation (Figs. 1 and 2). Therefore, unveiling the downstream signaling mechanism mediated by PI3K seems to be important step for understanding the mechanism of many physiological responses.

Our study demonstrated that PI3K regulated the generation of ROS in cancer cells (Fig. 2). The mechanism by
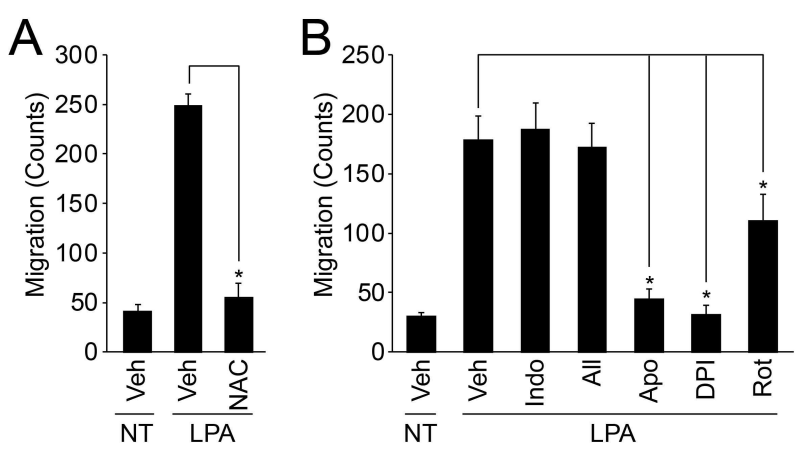

Fig. 4. Induction of migration by ROS. (A) SKOV-3 ovarian cancer cells were pretreated with ROS scavenger (NAC, 10 $\mu \mathrm{M})$ for $20 \mathrm{~min}$ and LPA-induced migration was measured. (B) Cells were pretreated with COX inhibitor (Indo, indomethacin, $10 \mu \mathrm{M}$ ), xanthine oxidase inhibitor (All, allopurinol, $10 \mu \mathrm{M}$ ), NADPH oxidase inhibitors (Apo, apocyanin, $10 \mu \mathrm{M}$; DPI, diphenylene iodonium, 10 $\mu \mathrm{M})$, or mitochondrial respiratory chain complex inhibitor (Rot, rotenone, $10 \mu \mathrm{M}$ ) and LPA-induced migration was measured. Data are the means \pm S.D. of three independent experiments ( $n=3$ for each experiment). *Significantly different from controls $(p<0.05)$. 
which PI3K regulates ROS generation is still not clear. However, recent report suggested that platelet-derived growth factor (PDGF) induces translocation of Rac1 and $\mathrm{p} 47^{\text {phox }}$ in PI3K-dependent mechanism [1]. Since Rac1 and $\mathrm{p} 47^{\text {phox }}$ are components of NADPH oxidase system, translocation of these two components supposed to lead activation of NADPH oxidase at plasma membrane thereby induces generation of ROS. Likewise, it is possible that LPA also activates PI3K to induce the activation of Rac followed by activation of NADPH oxidase. It is still unclear how $\mathrm{PIP}_{3}$ which is a catalytic product of PI3K leads to the activation of Rac. One possible mechanism might be activation of P-Rex1 which is a guanine nucleotide exchange factor (GEF) for Rac. P-Rex1 has pleckstrin homology (PH) domain, known as binding domain for $\mathrm{PIP}_{3}$, and two DEP domains, known as binding domain for $\mathrm{G}_{\beta \gamma}[12,34,36]$. Therefore, it is possible that $G$ protein-coupled LPA receptor evokes activation of PI3K and release of $G_{\beta \gamma}$ subunit and leads to the activation of P-Rex1. In line with this, it has been reported that LPA induces cancer cell migration through the activation of P-Rex1 [15].

In the present study, one important issue arises against involvement of Akt in the generation of ROS. For instance, inhibition of Akt abrogated LPA-induced migration as well as ROS generation (Figs. 1 and 2). Recently, the role of Akt in the activation of Rac has been reported. Overexpression of constitutively active form of Akt elevated activation of Rac [11]. On the other hand, overexpression of dominant negative form of Akt suppresses Rac activation. It also has been reported that silencing of Akt1 significantly reduced growth factor-induced activation of Rac [16]. Currently, the mechanism by which Akt regulates Rac activation is still unknown. One possible mechanism seems to be molecular complex formation of Akt, P-Rex1, and Rac with mTOR. For instance, Akt1 and P-Rex1 co-immunoprecipitated with mTOR [10], and confocal microscopic analysis revealed that Akt1, P-Rex1, and Rac co-localized at membrane ruffling region [16]. Therefore, Akt may relay the PI3K signals to Rac by formation of molecular complex and lead to the generation of ROS.

A number of evidence supports that growth factor receptor-induced ROS generation is key regulator for cell migration [13,22]. However, little is known about the involvement of ROS in LPA-induced cancer cell migration. In the present study, two major findings are suggested. First, LPA generates ROS through the activation of NADPH oxidase
(Fig. 3). Second, generation of ROS is important for LPA-induced migration of SKOV-3 ovarian cancer cells (Fig. 4). It is possible that the first issue involving mechanism of ROS generation seems to be regulated by P-Rex1/Rac signaling pathway as we mentioned above. However, it is still unclear how ROS regulates cell migration. One plausible mechanism seems to be enhancement of signaling capacity by modifying various molecules. For example, ROS can directly activate Src kinases by oxidizing its cysteine residues or indirectly by inhibiting protein tyrosine phosphatase (PTP) [4]. It also has been reported that inactivation of PTEN is achieved by ROS and this process is critical step for the activation of PI3K [27]. Therefore, it is possible that ROS can modulate signaling cascade involving regulatory mechanism of cancer cell migration.

In summary, LPA strongly promotes cancer cell migration and ROS generation. PI3K/Akt signaling pathway is necessary for both responses. In particular, generation of ROS plays essential roles in migration of cancer cells. Therefore, it is likely that PI3K/Akt signaling pathway regulates cancer cell migration through the generation of ROS.

\section{Acknowledgement}

This work was supported for two years by Pusan National University Research Grant.

\section{References}

1. Baumer, A. T., Ten Freyhaus, H., Sauer, H., Wartenberg, M., Kappert, K., Schnabel, P., Konkol, C., Hescheler, J., Vantler, M., and Rosenkranz, S. 2008. Phosphatidylinositol 3-kinase-dependent membrane recruitment of Rac-1 and p47phox is critical for a-platelet-derived growth factor receptor-induced production of reactive oxygen species. $J$. Biol. Chem 283, 7864-7876.

2. Bian, D., Su, S., Mahanivong, C., Cheng, R. K., Han, Q., Pan, Z. K., Sun, P., and Huang, S. 2004. Lysophosphatidic Acid Stimulates Ovarian Cancer Cell Migration via a Ras-MEK Kinase 1 Pathway. Cancer Res. 64, 4209-4217.

3. Chen, Q., Olashaw, N. and Wu, J. 1995. Participation of reactive oxygen species in the lysophosphatidic acid-stimulated mitogen-activated protein kinase kinase activation pathway. J. Biol. Chem 270, 28499-28502.

4. Chiarugi, P. 2008. Src redox regulation: there is more than meets the eye. Mol. Cells 26, 329-337.

5. Contos, J. J., Ishii, I. and Chun, J. 2000. Lysophosphatidic acid receptors. Mol. Pharmacol. 58, 1188-1196.

6. Dujardin, D. L., Barnhart, L. E., Stehman, S. A., Gomes, E. R., Gundersen, G. G. and Vallee, R. B. 2003. A role for cyto- 
plasmic dynein and LIS1 in directed cell movement. J. Cell Biol. 163, 1205-1211.

7. Etienne-Manneville, S. and Hall, A. 2003. Cdc42 regulates GSK-3 $\beta$ and adenomatous polyposis coli to control cell polarity. Nature $421,753-756$.

8. Fishman, D. A., Liu, Y., Ellerbroek, S. M. and Stack, M. S. 2001. Lysophosphatidic acid promotes matrix metalloproteinase (MMP) activation and MMP-dependent invasion in ovarian cancer cells. Cancer Res. 61, 3194-3199.

9. Han, J., Luby-Phelps, K., Das, B., Shu, X., Xia, Y., Mosteller, R. D., Krishna, U. M., Falck, J. R., White, M. A. and Broek, D. 1998. Role of substrates and products of PI 3-kinase in regulating activation of Rac-related guanosine triphosphatases by Vav. Science 279, 558-560.

10. Hernandez-Negrete, I., Carretero-Ortega, J., Rosenfeldt, H., Hernandez-Garcia, R., Calderon-Salinas, J. V., Reyes-Cruz, G., Gutkind, J. S., and Vazquez-Prado, J. 2007. P-Rex1 links mammalian target of rapamycin signaling to Rac activation and cell migration. J. Biol. Chem 282, 23708-23715.

11. Higuchi, M., Masuyama, N., Fukui, Y., Suzuki, A. and Gotoh, Y. 2001. Akt mediates Rac/Cdc42-regulated cell motility in growth factor-stimulated cells and in invasive PTEN knockout cells. Curr. Biol. 11, 1958-1962.

12. Hill, K., Krugmann, S., Andrews, S. R., Coadwell, W. J., Finan, P., Welch, H. C., Hawkins, P. T. and Stephens, L. R. 2005. Regulation of P-Rex1 by phosphatidylinositol $(3,4,5)$-trisphosphate and G $\beta \gamma$ subunits. J. Biol. Chem 280, 4166-4173.

13. Huo, Y., Qiu, W. Y., Pan, Q., Yao, Y. F., Xing, K. and Lou, M. F. 2009. Reactive oxygen species (ROS) are essential mediators in epidermal growth factor (EGF)-stimulated corneal epithelial cell proliferation, adhesion, migration, and wound healing. Exp. Eye Res. 89, 876-886.

14. Imamura, F., Mukai, M., Ayaki, M., Takemura, K., Horai, T., Shinkai, K., Nakamura, H. and Akedo, H. 1999. Involvement of small GTPases Rho and Rac in the invasion of rat ascites hepatoma cells. Clin. Exp. Metastasis 17, 141-148.

15. Kim, E. K., Yun, S. J., Ha, J. M., Kim, Y. W., Jin, I. H., Woo, D. H., Lee, H. S., Ha, H. K. and Bae, S. S. 2012. Synergistic induction of cancer cell migration regulated by Gß $\gamma$ and phosphatidylinositol 3-kinase. Exp. Mol. Med 44, 483-491.

16. Kim, E. K., Yun, S. J., Ha, J. M., Kim, Y. W., Jin, I. H., Yun, J., Shin, H. K., Song, S. H., Kim, J. H., Lee, J. S., Kim, C. D. and Bae, S. S. 2011. Selective activation of Akt1 by mammalian target of rapamycin complex 2 regulates cancer cell migration, invasion, and metastasis. Oncogene 30, 2954-2963.

17. Koh, J. S., Lieberthal, W., Heydrick, S. and Levine, J. S. 1998. Lysophosphatidic acid is a major serum noncytokine survival factor for murine macrophages which acts via the phosphatidylinositol 3-kinase signaling pathway. J. Clinic. Invest. 102, 716-727.

18. Lauffenburger, D. A. and Horwitz, A. F. 1996. Cell migration: a physically integrated molecular process. Cell 84, 359-369.

19. Liou, G. Y. and Storz, P. 2010. Reactive oxygen species in cancer. Free Radic. Res. 44, 479-496.

20. Maffucci, T., Cooke, F. T., Foster, F. M., Traer, C. J., Fry, M. J. and Falasca, M. 2005. Class II phosphoinositide 3-kinase defines a novel signaling pathway in cell migration. $J$. Cell Biol. 169, 789-799.

21. Malchinkhuu, E., Sato, K., Horiuchi, Y., Mogi, C., Ohwada, S., Ishiuchi, S., Saito, N., Kurose, H., Tomura, H. and Okajima, F. 2005. Role of p38 mitogen-activated kinase and c-Jun terminal kinase in migration response to lysophosphatidic acid and sphingosine-1-phosphate in glioma cells. Oncogene 24, 6676-6688.

22. Meng, D., Lv, D. D. and Fang, J. 2008. Insulin-like growth factor-I induces reactive oxygen species production and cell migration through Nox4 and Rac1 in vascular smooth muscle cells. Cardiovasc. Res. 80, 299-308.

23. Oikawa, T., Yamaguchi, H., Itoh, T., Kato, M., Ijuin, T., Yamazaki, D., Suetsugu, S. and Takenawa, T. 2004. PtdIns $(3,4,5) \mathrm{P} 3$ binding is necessary for WAVE2-induced formation of lamellipodia. Nat. Cell Biol. 6, 420-426.

24. Panetti, T. S., Nowlen, J. and Mosher, D. F. 2000. Sphingosine-1-phosphate and lysophosphatidic acid stimulate endothelial cell migration. Arterioscler. Thromb. Vasc. Biol. 20, 1013-1019.

25. Pietruck, F., Busch, S., Virchow, S., Brockmeyer, N. and Siffert, W. 1997. Signalling properties of lysophosphatidic acid in primary human skin fibroblasts: role of pertussis toxin-sensitive GTP-binding proteins. Naunyn-Schmiedebergs Arch Pharmacol. 355, 1-7.

26. Raftopoulou, M. and Hall, A. 2004. Cell migration: Rho GTPases lead the way. Dev. Biol. 265, 23-32.

27. Rhee, S. G., Kang, S. W., Jeong, W., Chang, T. S., Yang, K. S. and Woo, H. A. 2005. Intracellular messenger function of hydrogen peroxide and its regulation by peroxiredoxins. Curr. Opin. Cell Biol. 17, 183-189.

28. Ridley, A. J., Schwartz, M. A., Burridge, K., Firtel, R. A., Ginsberg, M. H., Borisy, G., Parsons, J. T. and Horwitz, A. R. 2003. Cell migration: integrating signals from front to back. Science 302, 1704-1709.

29. Russo, C., Gao, Y., Mancini, P., Vanni, C., Porotto, M., Falasca, M., Torrisi, M. R., Zheng, Y. and Eva, A. 2001. Modulation of oncogenic DBL activity by phosphoinositol phosphate binding to pleckstrin homology domain. J. Biol. Chem 276, 19524-19531.

30. Sasaki, A. T., Chun, C., Takeda, K. and Firtel, R. A. 2004. Localized Ras signaling at the leading edge regulates PI3K, cell polarity, and directional cell movement. J. Cell Biol. 167, 505-518.

31. Saunders, J. A., Rogers, L. C., Klomsiri, C., Poole, L. B. and Daniel, L. W. 2010. Reactive oxygen species mediate lysophosphatidic acid induced signaling in ovarian cancer cells. Free Radic. Biol. Med 49, 2058-2067.

32. Shah, B. H., Neithardt, A., Chu, D. B., Shah, F. B. and Catt, K. J. 2006. Role of EGF receptor transactivation in phosphoinositide 3-kinase-dependent activation of MAP kinase by GPCRs. J. Cell. Physiol. 206, 47-57.

33. Srinivasan, S., Wang, F., Glavas, S., Ott, A., Hofmann, F., 
Aktories, K., Kalman, D. and Bourne, H. R. 2003. Rac and Cdc42 play distinct roles in regulating $\mathrm{PI}(3,4,5) \mathrm{P} 3$ and polarity during neutrophil chemotaxis. J. Cell Biol. 160, 375-385.

34. Weiner, O. D. 2002. Rac activation: P-Rex1 - a convergence point for PIP(3) and Gß $\gamma$ ? Curr. Biol. 12, R429-431.

35. Weiner, O. D. 2002. Regulation of cell polarity during eukaryotic chemotaxis: the chemotactic compass. Curr. Opin. Cell Biol. 14, 196-202.

36. Welch, H. C., Coadwell, W. J., Ellson, C. D., Ferguson, G.
J., Andrews, S. R., Erdjument-Bromage, H., Tempst, P., Hawkins, P. T. and Stephens, L. R. 2002. P-Rex1, a PtdIns $(3,4,5) \mathrm{P} 3$ - and G $\beta \gamma$-regulated guanine-nucleotide exchange factor for Rac. Cell 108, 809-821.

37. Xu, Y., Shen, Z., Wiper, D. W., Wu, M., Morton, R. E., Elson, P., Kennedy, A. W., Belinson, J., Markman, M. and Casey, G. 1998. Lysophosphatidic acid as a potential biomarker for ovarian and other gynecologic cancers. JAMA 280, 719-723.

초록 : SKOV-3 난소암 세포주에서 Iysophosphatidic acid 유도 세포의 이동에 있어 활성산소의 역할

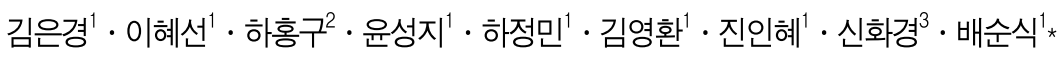

( ${ }^{1}$ 부산대학교 의학전문대학원 약리학교실, ${ }^{2}$ 부산대학교병원 비뇨기과학교실, ${ }^{3}$ 부산대학교 한의학전문대학원 해부학교실)

세포의 이동은 성장, 면역 작용, 그리고 혈관 신생 등 많은 생리현상에 중요한 역할을 한다. 또한 염증 및 종양 세포 침윤 등의 다양한 병리적 현상과도 밀접한 연관이 있다. 본 연구에서는 lysophosphatidic acid (LPA)는 활성 산소의 생성을 통해 SKOV-3 난소암세포의 이동을 조절한다는 것을 관찰하였다. 먼저, 난소 암세포인 SKOV-3에 서 LPA에 의한 세포의 이동이 강하게 일어남을 확인하였다. LPA에 의한 SKOV-3 세포의 이동은 phosphatidylinositol 3-kinase (PI3K)/Akt 신호전달체계를 저해시키는 약물에 의해서 완벽히 억제됨을 확인하였으나 ERK 신 호전달체계를 저해시키는 약물에 의해서는 전혀 영향을 받지 않았다. 그리고 SKOV-3 세포에서 LPA에 의한 활성 산소 형성이 시간에 따라 강하게 일어남을 확인하였다. 더욱이 LPA에 의한 활성산소 형성도 PI3K 또는 Akt의 저해제에 의해서 완벽히 억제됨을 확인하였으나 ERK 신호전달을 억제하였을 때는 거의 영향을 받지 않았다. SKOV-3 세포에서 LPA에 의해 생성된 활성산소는 diphenylene idonium (DPI, $10 \mu \mathrm{M})$, apocyanin (Apo, $10 \mu \mathrm{M}$ ) 과 같은 NADPH oxidase 억제제를 전 처리하였을 때 활성산소가 형성되지 못함을 관찰하였다. 그러나 xanthine oxidase (allopurinol, Allo, $10 \mu \mathrm{M}$ ), cyclooxygenase (indomethacin, Indo, $10 \mu \mathrm{M}$ ), 또는 mitochondrial respiratory chain complex I (rotenone, Rot, $10 \mu \mathrm{M}$ )를 억제하였을 때는 LPA에 의한 활성산소 형성에 영향을 주지 못함을 확인하였다. 마지막으로 활성산소 억제제인 N-acetylcysteine $(\mathrm{NAC}, 10 \mu \mathrm{M})$ 에 의해서 LPA에 의한 암세포의 이동 이 억제됨을 관찰하였다. 이와 더불어 LPA에 의한 SKOV-3 세포의 이동도 NADPH oxidase 억제에 의해 저해가 됨을 확인하였다. 이러한 연구결과로 보아 LPA에 의한 활성산소의 형성에는 PI3K/Akt/NADPH oxidase 신호전 달체계가 중추적인 역할을 하며 이를 통해 암세포의 이동을 조절한다는 것을 알 수 있었다. 